\title{
Evaluation of the Effect of a Home Bleaching Agent on Surface Characteristics of Indirect Esthetic Restorative Materials-Part II Microhardness
}

\author{
${ }^{1}$ Kianoosh Torabi, ${ }^{2}$ Sasan Rasaeipour, ${ }^{3}$ Safoura Ghodsi, ${ }^{4}$ Amir Ali Reza Khaledi, ${ }^{5}$ Mahroo Vojdani
}

\begin{abstract}
Background: The exponential usage of esthetic restorative materials is beholden to society needs and desires. Interaction between the bleaching agents and the esthetic restorative materials is of critical importance.
\end{abstract}

Aim: This in vitro study has been conducted to evaluate the effect of a home bleaching agent, carbamide peroxide (CP) $38 \%$, on the microhardness of the fiber reinforced composite (FRC), overglazed, autoglazed, or polished porcelain specimens.

Materials and methods: For overglazed, autoglazed, polished ceramics and also FRC cylindrical specimens ( $n=20$ per group) were prepared. The specimens were stored in distilled water at $37^{\circ} \mathrm{C}$ for 48 hours prior to testing. Six samples from each group were selected randomly as negative controls which were stored in distilled water at $37^{\circ} \mathrm{C}$ that was changed daily. CP $38 \%$ was applied on the test specimens for 15 minutes, twice a day for 14 days. By using Knoop-microhardness tester microhardness testing for baseline, control and test specimens was conducted. Data were statistically analyzed using paired t-test, MannWhitney test, and Kruskal-Wallis test.

Results: Home bleaching significantly decreased the surface microhardness of all the test samples $(p<0.05)$, whereas the control groups did not show statistically significant changes after 2 weeks. The polished porcelain and polished composite specimens showed the most significant change in microhardness after bleaching process $(p<0.05)$.

Conclusion: Although the type of surface preparation affects the susceptibility of the porcelain surface to the bleaching agent, no special preparation can preclude such adverse effects.

Clinical Significance: The contact of home bleaching agents with esthetic restorative materials is unavoidable. Therefore

\footnotetext{
${ }^{1}$ Associate Professor, ${ }^{2-4}$ Assistant Professor, ${ }^{5}$ Professor

${ }^{1,4}$ Department of Prosthodontics, Shiraz University of Medical Sciences, Shiraz, Iran

${ }^{2,3}$ Dental Research Center Dentistry Research Institute Tehran/Shiraz Universities of Medical Sciences, Tehran/ Shiraz, Iran

${ }^{5}$ Biomaterial Research Center, Shiraz University of Medical Sciences, Shiraz, Iran
}

Corresponding Author: Safoura Ghodsi, Assistant Professor Dental Research Center Dentistry Research Institute, Tehran/ Shiraz Universities of Medical Sciences, Tehran/Shiraz, Iran e-mail: s-ghodsi@ sina.tums.ac.ir protecting these restorations from bleaching agents and reglazing or at least polishing the restorations after bleaching is recommended.

Keywords: Bleaching, Esthetic restorative materials, Microhardness, Porcelain, Fiber reinforced composite.

How to cite this article: Torabi K, Rasaeipour S, Ghodsi S, Khaledi AAR, Vojdani M. Evaluation of the Effect of a Home Bleaching Agent on Surface Characteristics of Indirect Esthetic Restorative Materials - Part II Microhardness. J Contemp Dent Pract 2014;15(4):438-443.

Source of support: Nil

Conflict of interest: None declared

\section{INTRODUCTION}

Esthetics, by definition, is the science of beauty, the particular detail of an animate or inanimate object that makes appealing to the eye. ${ }^{1}$

The last three decades have witnessed massive changes in dentistry. ${ }^{2}$ Perhaps the most significant change was emphasis on esthetics in contemporary dentistry. The appearance of a smile is an important and impressive factor in esthetics which is affected by several different factors like tooth shape, texture, position and color. Since 30 years ago, the teeth were treated predominantly by invasive methods like prosthetic options for esthetic purposes. Today more conservative and economic bleaching methods are granted and tooth bleaching has become a well-liked modality to whiten discolored teeth. ${ }^{3}$ With choosing a correct patient and having a careful diagnosis, case selection, treatment planning, and attention to technique; bleaching would be the simplest, least invasive, least expensive way available to lighten discolored teeth. ${ }^{4}$

Close and fairly prolonged contact of bleaching materials with tooth structure and pre-existing restorations, raised apprehensions about their effects on the enamel and restorative materials from the beginning of their introduction. Researchers have shown that home bleaching is a safe technique with regard to its effect on tooth structure, ${ }^{5-9}$ but some concerns remain on its possible effect on restorative materials. ${ }^{10-13}$ It is not clear if the bleaching agents could harm the quality and longevity of these restorations.

The hardness of the materials is related to their strength, proportional limit and their ability to abrade or to be abraded 
by opposing dental structures or materials. If any chemical softening be resulted from the bleaching process, the clinical durability of the restorations would be jeopardized.

There is controversy about the impact of low concentrated $\mathrm{CP}$ gels on surface microhardness of restorative composite materials. A reduction in microhardness in resin-based composites is expected owing to their organic matrix content, which, according to many authors, is the probable site of the oxidation reaction ${ }^{15-17}$ but there is disparity in this field. The hardness of resin-based composites exposed to bleaching products has been reported to be increased, ${ }^{17-22}$ decreased, ${ }^{14,17,23}$ or remained unchanged. ${ }^{24-28}$

The hardness of porcelain has not been investigated as much as the aforementioned materials however available studies show contradictory results. Polydorou ${ }^{22,28}$ found that in-office ( $38 \% \mathrm{HP})$ and at-home (15\% CP) bleaching agents did not affect the microhardness of the ceramics 30 days after the bleaching procedure was finished. ${ }^{28} \mathrm{How}-$ ever, these findings are in conflict with those of Turker ${ }^{17}$ who reported significant decreases in the surface microhardness of feldspathic porcelain after a 30-day exposure to CP 10$16 \%$ for 8 hours daily. Fahmy ${ }^{29}$ showed that practices like glazing, bleaching, and saliva storage have an important effect on microhardness, fracture toughness and crack length of ultra low fusing ceramic.

With this foreword, it appears necessary to further investigate this issue to obtain safe durable results or to find a method to reduce its risks if negative side effects were established.

The aim of this study was to evaluate the effect of a home bleaching agent (CP: $38 \%$ ) on the microhardness of the FRC, overglazed, autoglazed, or polished porcelain samples.

\section{MATERIALS AND METHODS}

In this study, ceramic disks (10 $\mathrm{mm}$ diameter, $6 \mathrm{~mm}$ thick) were used for standardization.

Preparation of the specimen was carried out in three phases:

In the first phase cylindrical metallic molds were constructed. For this purpose according to Turker et al study ${ }^{17}$ two pieces of $6 \mathrm{~mm}$ stainless steel disks were held together by a weld. Before welding, four $1 \mathrm{~cm}$ diameter holes were bored in one of the plates. In this way holes with a flat and parallel bottom were produced. The metal mold was boxed, and poured with a silicon duplicate impression material in accordance with the manufacturer's directions. Refractory material in a powder: liquid ratio of 3:1 was mixed using a vacuum mixer and poured over the silicon molds using a vibrator. When the material had set, negative investments were removed from the silicon duplicating mold. This procedure was repeated until 80 investments were produced.

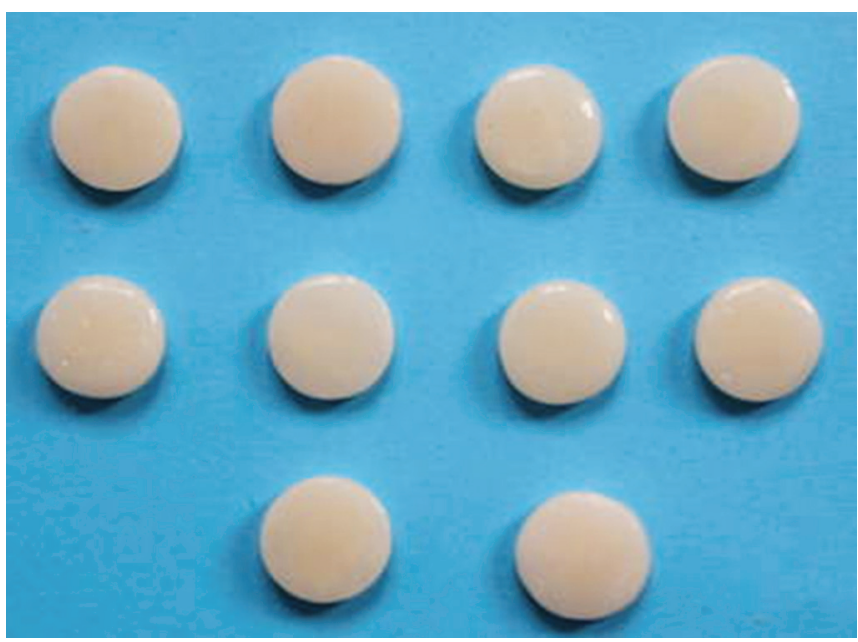

Fig. 1: Ceramic samples

Three groups of feldspathic porcelain ( $\mathrm{n}=20$ per group) were prepared by condensing porcelain (Duceram loveDegu Dent GmbH-DENTSPLY-Germany) into the molds and firing in vacuum furnace according to manufacturer's instructions. The defects were adjusted with corrective addon porcelain firing. After air cooling at room temperature, the ceramic disks were ground flat and wet polished with progressively finer grit aluminium oxide abrasive papers (Fig. 1).

For surface preparation phase, the porcelain samples were divided into three groups: The overglazed porcelain (OP) and the autoglazed porcelain (AP) groups were glazed in accordance to manufacturer's instructions. For the third group, polished porcelain (POP), the samples were polished. The polishing process was done with medium, fine and superfine Sof-Lex (3M) disks on a slow-speed hand-piece according to the manufacturer's instructions.

For the forth group: The condensable veneering composite of the fiber reinforced composite system (Adoro SR-Ivoclar Vivadent-Germany) was packed into the molds. Adoro pastes were applied and cured according to manufacturer's instructions. The entire veneering surface was covered with SR gel to prevent forming an air inhibition layer. After completion of polymerization, each sample was ground flat using tungsten carbide bur, fine diamond and flexible disk on slow-speed hand-piece to remove an air inhibition layer. They were polished using silicone wheels, cotton buff and universal polishing paste: emulsion comprising aluminum oxide, aluminum oleate, petroleum distillate and water according to producer's instructions.

All samples were cleaned with air-water spray for 1 minute and stored in distilled water at $37^{\circ} \mathrm{C}$ for 48 hours. Afterwards, six samples from each group were selected randomly to form negative controls. The microhardness tests were done for each sample as baseline measurement, therefore each sample assumed to be its own control. 
Table 1: Mean baseline hardness values

\begin{tabular}{lllll}
\hline Groups & Mean & SD & Minimum & Maximum \\
\hline OP & 565.92 & 9.53 & 552.90 & 578.00 \\
AP & 581.74 & 20.00 & 542.90 & 611.50 \\
POP & 566.05 & 33.74 & 507.30 & 623.90 \\
FRC & 44.90 & 8.09 & 32.60 & 57.90 \\
\hline
\end{tabular}

OP: Overglazed porcelain; AP: Autoglazed porcelain; POP: Polished porcelain; FRC: Fiber reinforced composite

For Knoop microhardness test, a hardness tester was used (Wolpert Wilson Vickers/Knoop hardness testers -WILSON Instruments-USA). The load of 500 gm was used for porcelain samples and the load of $50 \mathrm{gm}$ was used for composite samples, for all groups the loading time was 30 seconds.

The bleaching procedure was done for each test sample at $37^{\circ} \mathrm{C}$. The top-surface of 14 samples from each group were covered completely with bleaching material (38\% CP: DayWhite ACP -Discus Dental-USA) for 15 minutes, twice a day with 3 hours intervals over a period of 2 weeks. Between each bleaching exposure, the exposed specimens were washed with soft brush under running distilled water for 1 minute and maintained in fresh distilled water at $37^{\circ} \mathrm{C}$ till the next bleaching application. The negative controls were stored in distilled water at $37^{\circ} \mathrm{C}$ which was changed daily after washing the samples with soft brush under running distilled water for 1 minute to resemble the normal conditions.

After 2 weeks, microhardness tests were done for each sample in a similar manner to baseline measurements; all readings were performed by the same operator to eliminate inter-operators bias. The paired-t-test, Mann-Whitney test, and Kruskal-Wallis test were enrolled for statistical analysis.

\section{RESULTS}

Table 1 presents the mean base line surface microhardness values (Knoop Hardness Number: KHN), and standard

Table 3: Baseline- test (after bleaching) mean hardness differences

\begin{tabular}{lllllll}
\hline Groups & Mean & $S D$ & SE & $t$ & $p$ & $\begin{array}{l}\text { Eff. size } \\
\text { Mean diff/SD }\end{array}$ \\
\hline OP & 6.02 & 6.06 & 1.62 & 3.71 & 0.00 & 0.99 \\
AP & 6.38 & 9.49 & 2.53 & 2.51 & 0.02 & 0.67 \\
POP & 61.52 & 31.47 & 8.41 & 7.31 & 0.00 & 1.95 \\
FRC & 12.12 & 7.64 & 2.04 & 5.93 & 0.00 & 1.58
\end{tabular}

OP: Overglazed porcelain; AP: Autoglazed porcelain; POP: Polished porcelain; FRC: Fiber reinforced composite
Table 2: Baseline - control mean hardness differences

\begin{tabular}{llllll}
\hline Groups & Mean & $S D$ & $S E$ & $t$ & $p$ \\
\hline OP & -2.73 & 21.98 & 8.97 & -0.30 & 0.77 \\
AP & -16.51 & 21.75 & 8.88 & -1.86 & 0.12 \\
POP & -10.11 & 24.65 & 10.06 & -1.00 & 0.36 \\
FRC & -1.95 & 7.07 & 2.88 & -0.67 & 0.52 \\
\hline
\end{tabular}

OP: Overglazed porcelain; AP: Autoglazed porcelain; POP: Polished porcelain; FRC: Fiber reinforced composite

deviations for all groups. Group statistics showed that, before bleaching procedure the mean microhardness of the composite specimens was much lower than the ceramics. The differences between the mean hardness of the porcelain samples seem not to be remarkable but the total mean microhardness of the autoglazed specimens was higher than the polished and the overglazed porcelain samples. Tables 2 and 3 present the statistical comparisons of Knoop- microhardness mean values within each group. The microhardness of the control specimens was found to be stable after 2 weeks compared with their baseline quantities, but bleaching with $38 \% \mathrm{CP}$ affected the microhardness of all the test samples significantly $(p<0.05)$. The most significant change in microhardness occurred in polished porcelain and polished composite samples. The effect of bleaching on surface microhardness of the autoglazed ceramic specimens was less than the overglazed samples; nevertheless even the hardness of autoglazed samples decreased significantly after bleaching process. According to Table 4, the types of surface preparations cause statistically significant differences between the microhardness of the porcelain subgroups $(\mathrm{p}<0.05)$.

\section{DISCUSSION}

Interaction between whitening agents and esthetic restorative materials is of critical importance while there is a need for a prolonged contact between bleaching agents and dental structure to allow the oxidation process to happen. ${ }^{30}$ The oxidation procedure and low resulting $\mathrm{pH}$ has been considered as a potential source of adverse effects. ${ }^{31}$ Surface alterations are clinically important properties that merit investigation, since these deleterious impacts can endanger the esthetic and durability of restoration and the long-term health of oral structures. ${ }^{32}$

In this study, the effect of one bleaching agent (CP: 38\%) on porcelain material and FRC was evaluated. Porcelain

Table 4: Statistical analysis of porcelain subgroups

\begin{tabular}{lllll}
\hline Groups & Median & Mean $\pm S D$ & $\begin{array}{l}\text { p Based on Kruskal-Wallis } \\
\text { test }\end{array}$ & $\begin{array}{l}\text { Significant pairwise comparisons } \\
\text { based on Mann-Whitney test }\end{array}$ \\
\hline OP - baseline & -5.05 & $-6.02 \pm 6.06$ & $<0.001$ & OP vs AP $(p=0.000)$ \\
AP - baseline & -2.60 & $-6.38 \pm 9.49$ & $<0.001$ & OP vs POP $(p=0.000)$ \\
POP - baseline & -60.50 & $-61.52 \pm 31.47$ & $<0.001$ & AP vs POP $(p=0.000)$ \\
\hline
\end{tabular}

OP: Overglazed porcelain; AP: Autoglazed porcelain; POP: Polished porcelain; FRC: Fiber reinforced composite 
specimens were divided in three groups, according to surface treatment. The samples were stored in distilled water, in $37^{\circ} \mathrm{C}$ (mouth temperature), during the study period. This was planned according to Hao Yu et al who reported the environmental temperature influences the effect of bleaching on surface microhardness of restorative materials. ${ }^{33}$ Campos et $\mathrm{al}^{27}$ used saliva to simulate oral conditions. It is reported that the substances present in saliva may act as accelerators in degrading CP and may reduce its adverse effects by means of the salivary remineralizing potential. ${ }^{34}$ Because the aim of the present study was to examine the effect of the bleaching agents without the parallel effect of other parameters (saliva), distilled water was chosen as storage solution. The samples exposed to the $\mathrm{CP}, 15$ minutes, twice a day for 2 weeks according to manufacturer's instructions. This was in contrast to several other bleaching studies, where materials were exposed continuously to bleaching products for several days to simulate cumulative effects over a period of time. ${ }^{15,35,36}$ The frequency of applying of bleaching agents may contribute to the disparity in results. The wide variations in literature results, regarding microhardness, suggest that some tooth-colored restorative materials may be more susceptible to alternations and some bleaching agents are more likely to cause those alternations. ${ }^{37}$ The latter may be attributed to the differences in $\mathrm{pH}$ between bleaching agents. ${ }^{38}$

In this study, the bleaching agent decreased the hardness of FRC samples significantly which is in line with the results reported by Hannig, ${ }^{39}$ Lima, $^{40}$ and Taher. ${ }^{41}$ Langsten $^{42}$ showed that composite matrices composed of (Bis GMA) could be softened by chemical substances with similar solubility parameter in our study, the urethane dimethacrylate (UDMA) matrices show similar reaction. The hardness of a material is correlated with the resin-filler bonding and also inorganic filler content; ${ }^{43}$ therefore it could be supposed that the effect of the bleaching agents on this content could also be the reason for the changes of the microhardness of the restorative materials after bleaching. Chemical softening of composite resins is believed to occur in vivo, contributing to wear of the resin in both stress-bearing and non-stressbearing areas. ${ }^{44-46}$

In our study, we observed that the home bleaching agent reduced the microhardness of porcelain as well. The bleaching effect on polished samples was more noticeable, whereas the glazed specimens (even over or auto glazed) showed less influences. Although, these impacts were significant statistically, the small amount of released $\mathrm{SiO}_{2}$ content might not be perceptible clinically. It seems that glazed surface decreases the penetration and the influence of agents on ceramic materials. This can be important when frequent adjustment of porcelain in the patient's mouth is needed which removes the glazed surface. Polishing the adjusted area may not be as protective as glaze. Since, all changes were significant, apparently even protective glaze layer cannot preserve the porcelain from all the environmental changes.

With the availability of two types of peroxide in multiple concentrations, the lack of consensus about the effects of bleaching agents on restorative materials among the authors reviewed in this article is not surprising. As the new bleaching agents with various concentrations and application instructions are introduced, their applications are increased due to increased patients' demands. Accordingly, the concerns about their potential adverse effects on dental restorations and patients' general health are also increased. While similar studies and existing controversies will improve the quality and safety of the new materials, dentists should be aware that the physical properties of some dental restorations can be altered by bleaching. ${ }^{47}$

The clinical relevance of the findings exhibited in this study is uncertain; however, it seems logical to consider precautionary measures to prevent any side-effects until the complete safety of bleaching materials is proven.

Further studies (preferably in vivo clinical study) are always entailed since new materials and technologies are introduced to dental profession.

\section{CONCLUSION}

The effect of home bleaching agent on the microhardness of the two different esthetic restorative materials can be concluded to:

The total mean microhardness of the AP specimens is higher than the polished and the overglazed samples.

The 38\% CP has significant effect on the microhardness of the FRC and the porcelain.

The type of surface preparation significantly affects the amenability of porcelain surface hardness from the bleaching agent.

Polished porcelain is influenced more when compared with glazed specimens, and autoglazed samples show the least hardness reduction.

Clinical implication: Home bleaching agents are easily accessible and their contacts with prevalent esthetic restorations is unavoidable, hence, protecting these restoration from bleaching agents and polishing or reglazing the restorations after bleaching procedure may be useful implications.

\section{ACKNOWLEDGMENTS}

The authors would like to thank the vice-chancellor of Shiraz University of Medical Sciences, for supporting the research (Grant\# 1425). This manuscript relevant thesis of Dr Safoura Ghodsi. Also the authors thank Dr Shahram Hamedani (DDs, $\mathrm{MSc}$ ) for editorial assistance. 


\section{REFERENCES}

1. Arens D. The role of bleaching in esthetics. Dent Clin North Am 1989 Apr;33(2):319-336.

2. Goldstein RE, Lancaster JS. Survey of patient attitudes toward current esthetic procedures. J Prosthet Dent 1984 Dec; 52(6):775-780.

3. Anderson MH. Dental bleaching. Curr Opin Dent 991 Apr; 1(2):185-191.

4. Wandera A, Feigal RJ, Douglas WH, Pintado MR. Home-use tooth bleaching agents: an in vitro study on quantitative effects on enamel, dentin, and cementum. Quintessence Int 1994 Aug; 25(8):541-546.

5. Matis BA, Cochran MA, Eckert G, Carlson TJ. The efficacy and safety of a $10 \%$ carbamide peroxide bleaching gel. Quintessence Int 1998 Sep;29(9):555-563.

6. Auschill TM, Hellwig E, Schmidale S, Hannig M, Arweiler NB. Effectiveness of various whitening techniques and their effects on the enamel surface [in German]. Schweiz Monatsschr Zahnmed 2002;112(9):894-900.

7. Zekonis R, Matis BA, Cochran MA, Al Shetri SE, Eckert GJ, Carlson TJ. Clinical evaluation of in-office and at-home bleaching treatments. Oper Dent 2003 Mar-Apr;28(2):114-121.

8. Al-Qunaian TA, Matis BA, Cochran MA. In vivo kinetics of bleaching gel with three-percent hydrogen peroxide within the first hour. Oper Dent 2003 May-Jun;28(3):236-241.

9. Auschill TM, Hellwig E, Schmidale S, Sculean A, Arweiler NB. Efficacy, side-effects and patients' acceptance of different bleaching techniques (OTC, in-office, at home). Oper Dent 2005 Mar-Apr;30(2):156-163.

10. Swift EJ Jr, Perdigão J. Effects of bleaching on teeth and restorations. Compend Contin Educ Dent 1998 Aug;19(8):815-820.

11. Fay RM, Servos T, Powers JM. Color of restorative materials after staining and bleaching. Oper Dent 1999 Sep-Oct;24(5):292-296.

12. Polydorou O, Hellwig E, Auschill TM. The effect of different bleaching agents on the surface texture of restorative materials. Oper Dent 2006 Jul-Aug;31(4):473-480.

13. Steinberg D, Mor C, Dogan H, Zacks B, Rotstein I. Effect of salivary biofilm on the adherence of oral bacteria to bleached and nonbleached restorative material. Dent Mater 1999 Jan;15(1):14-20.

14. Bailey SJ, Swift EJ. Effects of home bleaching products on composite resins. Quintessence Int 1992 Jul;23(7):489-494.

15. Cullen DR, Nelson JA, Sandrik JL. Peroxide bleaches: effect on tensile strength of composite resins. J Prosthet Dent 1993 Mar; 69(3):247-249.

16. Swift EJ Jr. Restorative considerations with vital tooth bleaching. J Am Dent Assoc 1997 Apr;128 Suppl:60S-64S.

17. Turker SB, Biskin $T$. The effect of bleaching agents on the microhardness of dental esthetic restorative materials. J Oral Rehabil 2002 Jul;29(7):657-661.

18. Cooley RL, Burger KM. Effect of carbamide peroxide on composite resins. Quintessence Int 1991;22(10):817-821.

19. Kelleher MG, Roe FJ. The safety-in-use of $10 \%$ carbamide peroxide (Opalescence) for bleaching teeth under the supervision of a dentist. Br Dent J 1999 Aug 28;187(4):190-194.

20. Oltu U, Gurgan S. Effects of three concentrations of carbamide peroxide on the structure of enamel. J Oral Rehabil 2000 Apr; 27(4):332-340.

21. Müjdeci A, Gökay O. Dental effects of home bleaching gels and whitening strips on the surface hardness of resin composites. Am J Dent 2005 Oct;18(5):323-326.
22. Polydorou O, Moenting JS, Hellwig E, Auschill TM. Effect of in-office tooth bleaching on the microhardness of six dental esthetic restorative materials. Dent Mater 2007 Feb;23(2):153-158.

23. Gurgan $\mathrm{S}$, Yalcin F. The effect of 2 different bleaching regimens on the surface roughness and hardness of tooth-colored restorative materials. Quintessence 2007 Feb;38(2):e83-87.

24. Nathoo SA, Chmielewski MB, Kirkup RE. Effects of colgate platinum professional toothwhitening system on microhardness of enamel, dentin, and composite resins. Compend Suppl 1994; (17):S627-S630.

25. Yap AU, Wattanapayungkul P. Effects of in-office tooth whiteners on hardness of tooth-colored restoratives. Oper Dent 2002 Mar-Apr;27(2):137-141.

26. Garcia-Godoy F, Garcia-Godoy A, Garcia-Godoy F. Effect of bleaching gels on the surface roughness, hardness and micromorphology of composites. Gen Dent 2002 May-Jun; 50(3):247-250.

27. Campos I, Briso AL, Pimenta LA, Ambrosano G. Effects of bleaching with carbamide peroxide gels on microhardness of restoration materials. J Esthet Restor Dent 2003;15(3):175-182.

28. Polydorou O, Hellwig E, Auschill TM. The effect of at-home bleaching on the microhardness of six esthetic restorative materials. J Am Dent Assoc 2007 Jul;138(7):978-984.

29. Fahmy NZ, El Guindy J, Zamzam M. Effect of artificial saliva storage on microhardness and fracture toughness of a hydrothermal glass-ceramic. J Prosthodont 2009 Jun; 18(4):324-331.

30. Li Y. Tooth bleaching using peroxide-containing agents: current status of safety issues. Compend Contin Educ Dent 1998 Aug; 19(8):783-786.

31. Lewinstein I, Fuhrer N, Churaru N, Cardash H. Effect of different peroxide bleaching regimens and subsequent fluoridation on the hardness of human enamel and dentin. J Prosthet Dent 2004 Oct; 92(4):337-342.

32. Moraes RR, Marimon JL, Schneider LF, Correr Sobrinho L, Camacho GB, Bueno M. Carbamide peroxide bleaching agents: effects on surface roughness of enamel, composite and porcelain. Clin Oral Investig 2006 Mar;10(1):23-28.

33. Yu H, Li Q, Cheng H, Wang Y. The effects of temperature and bleaching gels on the properties of tooth-colored restorative materials. J Prosthet Dent 2011 Feb;105(2):100-107.

34. Zalkind M, Arwaz JR, Goldman A, Rotstein I. Surface morphology changes in human enamel, dentin and cementum following bleaching: a scanning electron microscopy study. Endod Dent Traumatol 1996 Apr;12(2):82-88.

35. Monaghan P, Trowbridge T, Lautenschlager E. Composite resin color change after vital tooth bleaching. J Prosthet Dent 1992 Jun;67(6):778-781.

36. Monaghan P, Lim E, Lautenschlager E. Effects of home bleaching preparations on composite resin color. J Prosthet Dent 1992 Oct;68(4):575-578.

37. Swift EJ Jr, Perdigão J. Effects of bleaching on teeth and restorations. Compend Contin Educ Dent 1998 Aug;19(8):815-820.

38. Price RB, Sedarous M, Hiltz GS. The $\mathrm{pH}$ of tooth-whitening products. J Can Dent Assoc 2000 Sep;66(8):421-426.

39. Hannig C, Duong S, Becker K, Brunner E, Kahler E, Attin T. Effect of bleaching on subsurface microhardness of composite and a polyacid modified composite. Dent Mater 2007 Feb;23(2):198-203.

40. Lima DA, De Alexandre RS, Martins AC, Aguiar FH, Ambrosano GM, Lovadino JR. Effect of curing lights and bleaching agents on physical properties of a hybrid composite resin. J Esthet Restor Dent 2008;20(4):266-273.

41. Taher NM. The effect of bleaching agents on the surface hardness of tooth colored restorative materials. J Contemp Dent Pract 2005 May 15;6(2):18-26. 
42. Langsten RE, Dunn WJ, Hartup GR, Murchison DF. Higherconcentration carbamide peroxide effects on surface roughness of composites. J Esthet Restor Dent 2002;14(2):92-96.

43. Say EC, Civelek A, Nobecourt A, Ersoy M, Guleryuz C. Wear and microhardness of different resin composite materials. Oper Dent 2003 Sep-Oct;28(5):628-634.

44. Wu W, Toth EE, Moffa JF, Ellison JA. Subsurface damage layer of in vivo worn dental composite restorations. J Dent Res 1984 May;63(5):675-680.
45. van Groeningen G, Jongebloed W, Arends J. Composite degradation in vivo. Dent Mater 1986 Oct;2(5):225-227.

46. Sharafeddin F, Jamalipour GR. Effects of $35 \%$ carbamide peroxide gel on surface roughness and hardness of composite resins. J Dent TUMS 2010;7(1):6-12.

47. Torabi K, Rasaeipour S, Khaledi AA, Vojdani M, Ghodsi S. Evaluation of the Effect of a Home bleaching Agent on the Surface Characteristics of Indirect Esthetic Restorative Materials: Part I-Roughness. J Contemp Dent Pract 2014;15(3):324-328. 